\title{
Electrocoagulation using stainless steel anodes: Simultaneous removal of phosphates, Orange II and zinc ions
}

\author{
Adelaide Dura, Carmel B. Breslin* \\ Department of Chemistry, Maynooth University, Maynooth, County Kildare, Ireland
}

\section{A R T I C L E I N F O}

\section{Keywords:}

Electrocoagulation

Stainless steel

Chromium content

Phosphates

Dyes

Zinc ions

\begin{abstract}
A B S T R A C T
Two stainless steel anodes, AISI 420 and AISI 310, and pure iron were compared in an electrocoagulation study for the simultaneous removal of phosphates, Orange II and Zinc ions from a synthetic wastewater at a current density of $11.7 \mathrm{~mA} \mathrm{~cm}^{-2}$ and a surface area to volume ratio of $19.4 \mathrm{~m}^{-1}$. High removal efficiencies were observed with AISI 420 and pure iron, reaching values between $88 \%$ and $99 \%$, while significantly lower values, approximately $30 \%$, were obtained with AISI 310. The AISI 310 performed well in the removal of $\mathrm{Zn}^{2+}$ due to its removal as $\mathrm{Zn}(\mathrm{OH})_{2}$. The variations in the performance of the steel anodes were attributed to the lower chromium content of the AISI 420, which gives less passive behaviour. This was supported using polarisation data, where a 10-fold increase in the corrosion current was obtained for AISI 420 compared to AISI 310. Furthermore, $\mathrm{Cr}(\mathrm{VI})$ was observed in the solution phase when AISI 310 was employed as the anode, illustrating the importance of the alloying concentrations. While rust particles were seen during the non-continuous use of the iron anode, they were not observed with the AISI 420 anode.
\end{abstract}

\section{Introduction}

In recent years, as environmental regulations concerning wastewater become more stringent electrochemical technologies, particularly electrocoagulation, have become increasingly important and have received considerable attention [1-3]. In electrocoagulation, sacrificial anodes are employed and these usually involve iron or aluminium. As iron anodes are dissolved, $\mathrm{Fe}^{2+}$ ions are produced, while hydroxide ions and hydrogen gas are generated at the cathode in the cell [1], Eq. 1. An increase in the $\mathrm{OH}^{-}$concentration causes an increase in the solution $\mathrm{pH}$ and this results in the formation of various iron hydroxide species, including the insoluble $\mathrm{Fe}(\mathrm{OH})_{2}$. Also, $\mathrm{Fe}^{3+}$ cations are electrochemically generated when the anode reaches high potentials, while in the presence of dissolved oxygen, the $\mathrm{Fe}^{2+}$ ions are oxidised to $\mathrm{Fe}^{3+}$ ions to give insoluble $\mathrm{Fe}(\mathrm{OH})_{3}$. It is generally accepted that the $\mathrm{Fe}^{3+}$ cations favour the coagulation-flocculation process [1].

$\mathrm{H}_{2} \mathrm{O}+2 \mathrm{e}^{-} \rightarrow 2 \mathrm{OH}^{-}+\mathrm{H}_{2}(g)$

Electrocoagulation has been used to remove a large number of pollutants, including phosphates [4-6], nitrates [7], organic dye molecules [8,9], arsenic [7], chromium (VI) and fluoride [10] and heavy metal ions [11]. The removal of these species has been explained in terms of the adsorption of the pollutant on the iron hydrolysed products, mainly $\mathrm{Fe}(\mathrm{OH})_{3}$, adsorption of the pollutant species onto charged iron hydrolysis products, $\mathrm{Fe}(\mathrm{OH})_{\mathrm{n}}{ }^{3-\mathrm{n}}$, or the incorporation of the pollutant ions in the iron hydroxide-containing precipitates and hydrolysis products. The electrocoagulation process, and consequently the rate of removal of the pollutant, depends on the experimental conditions employed, including current density, the composition and arrangement of anodes and cathodes, flow rate of contaminated water, to concentration of the pollutant, the ionic nature and charge of the dissolved pollutants and the conductivity, composition and $\mathrm{pH}$ of the solution $[1,12]$. More recently, electrocoagulation has been employed in the microbial decontamination of water [13], illustrating its potential applications in water disinfection.

Electrocoagulation is ideally suited to small-scale or localised water treatment technologies and sometimes these are preferred to large-scale centralised facilities and especially in developing countries, where the supply of clean water is essential [14]. A localised plant has reduced costs and energy consumption compared with larger infrastructures and because of the low energy demand it can be coupled easily with a renewable energy source, such as solar or wind energy. Electrocoagulation has the added advantage that the metal cations are introduced in-situ rather than by external dosing, which is the case with chemical coagulation, and this prevents secondary pollution. Moreover, electrocoagulation is characterized by simple and easy to operate equipment,

\footnotetext{
* Corresponding author.

E-mail address: carmel.breslin@mu.ie (C.B. Breslin).
} 
short operation times, none, or negligible amounts of chemicals and low sludge production, compared to chemical coagulation.

Most of the electrocoagulation studies have focussed on iron and aluminium anodes, however stainless steel anodes have been employed in the removal of $\mathrm{Cr}(\mathrm{VI})$ [15], in the treatment of textile wastewaters [16,17], naphthalene compounds [18] and nitrophenol [19]. While pure iron is efficient in terms of anode dissolution and it is employed widely in electrocoagulation applications, some limitations in its use have been identified. For example, Chen and co-workers [20,21], and other authors [22,23], have reported the development of a yellowish colour at the end of the treatment, affecting the quality of the water. This yellowish colour has been attributed to the presence of fine particles of rust.

In this study stainless steel anodes were employed with the intention of avoiding this negative effect of rust. Two stainless steel alloys were selected, AISI 420 and AISI 310. These differ in terms of the chromium alloying concentration. The presence of chromium facilitates the formation of a protective or passive film, that prevents or minimises the formation of rust. However, this passive film will also limit the rate of dissolution and the production of $\mathrm{Fe}^{2+}$ and $\mathrm{Fe}^{3+}$. Therefore, this study was focussed on determining an appropriate chromium concentration level that will limit the formation of rust but not inhibit significantly the dissolution of the anode. Two stainless steel alloys were compared with iron in the simultaneous removal of phosphates, Orange II and $\mathrm{Zn}^{2+}$ ions from two synthetic wastewaters. These synthetic samples were chosen as they contain some of the ions most commonly found in wastewater. The two solutions differ in the chloride concentration and conductivity, and represent lower and elevated chloride levels that are typically found in water samples. These are two important parameters in electrocoagulation, as the solution conductivity and chloride concentration affect the rate of dissolution of the anode [1].

\section{Experimental}

All chemicals were supplied by Sigma-Aldrich ${ }^{\circ}$ The electrocoagulation tests were carried out in two synthetic wastewaters, sww1 and sww2, Table 1, which were formulated from the OECD synthetic sewage [24]. The iron and stainless steel alloys were supplied by Goodfellow $^{\odot}$ with the following compositions: AISI $420(13-14 \% \mathrm{Cr}$; $1 \% \mathrm{Mn} ; 1 \% \mathrm{Si} ; 0.3 \% \mathrm{C}$; and balance $\mathrm{Fe})$ and AISI $310(24-26 \% \mathrm{Cr}$; $19-22 \% \mathrm{Ni} ; 2 \% \mathrm{Mn} ; 1.5 \% \mathrm{Si} ; 0.25 \% \mathrm{C}$; balance Fe). The samples used in the electrocoagulation tests were abraded with water lubricated Buehler silicon carbide paper (Grit P 320 to P 2500), washed with deionised water and dried in a stream of air. The electrocoagulation tests were carried out using a steel cathode (AISI 310) and Fe, AISI 310 or AISI 420 as the anode at room temperature. A schematic of the cell is shown in Fig. 1, where a reference electrode was added to monitor the potential of the cell. The distance between the anode and the cathode was maintained at $1 \mathrm{~cm}$. A constant current density of $11.7 \mathrm{~mA} \mathrm{~cm}{ }^{-2}$ was used, the ratio of the surface area to the volume of solution, SA/V, was $19.4 \mathrm{~m}^{-1}$ and the solution was agitated. Samples were taken and allowed to settle for $15 \mathrm{~min}$. Then the supernatant was filtered with Whatman ${ }^{\mathrm{TM}}$ filter paper (pore size $11 \mu \mathrm{m}$ ) and the solution was analysed for the presence of phosphate, Orange II and $\mathrm{Zn}^{2+}$. All experiments were repeated at least three times and this is indicated by the $n$ value provided in the figure captions.

A Unicam Thermo Spectronic ${ }^{\circledR}$ UV 540 double-beam spectrometer

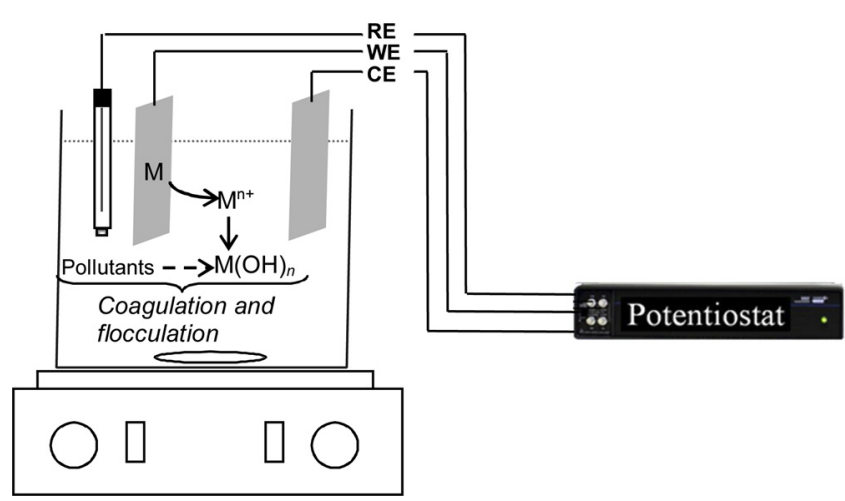

Fig. 1. Schematic illustrating the anode/cathode (WE/CE) electrocoagulation cell employed with a reference electrode (RE).

was used to determine the concentrations of phosphate and Orange II. The phosphate concentration was measured using the vanadomolybdophosphoric acid colorimetric method [25] at $470 \mathrm{~nm}$, while the Orange II was monitored at $485 \mathrm{~nm}$. The phosphate and Orange II concentrations were obtained by solving the simultaneous linear equations given in Eq. (2). Here, $A_{470}$ and $A_{485}$ are the absorbance values of the mixture at $470 \mathrm{~nm}$ and $485 \mathrm{~nm}, \varepsilon_{470}^{p}$ and $\varepsilon_{485}^{p}$ are the extinction coefficients of phosphate at 470 and $485 \mathrm{~nm}$ computed from the spectrum of pure phosphate. Likewise, $\varepsilon_{470}^{o}$ and $\varepsilon_{470}^{o}$ are the extinction coefficients of Orange II at $470 \mathrm{~nm}$ and $485 \mathrm{~nm}$ computed from the spectrum of the Orange II, while $C_{\mathrm{p}}$ and $C_{\mathrm{o}}$ are the concentrations of phosphate and Orange II, respectively.

$A_{470}=\varepsilon_{470}^{p} C_{P}+\varepsilon_{470}^{o} C_{o}$

$A_{485}=\varepsilon_{485}^{p} \mathrm{C}_{P}+\varepsilon_{485}^{o} \mathrm{C}_{0}$

The concentrations of $\mathrm{Zn}^{2+}$ were obtained using atomic absorption spectroscopy (AA) with a Perkin Elmer Analyst 200 AA spectrometer. The standard solutions were prepared by dissolving metallic zinc in $\mathrm{HNO}_{3}$.

The passive behaviour of the anodes was studied using polarisation experiments in a three-electrode cell with a saturated calomel reference electrode, a high surface area platinum wire and the iron or steel alloys as the working electrode. The electrodes were prepared and set in a Teflon ${ }^{\oplus}$ holder with epoxy resin. Electrical contact was made using a copper wire, which was threaded to the base of the sample. The exposed electrode surface was abraded on a Buehler Metaserve grinder polisher with water lubricated Buehler ${ }^{\circ} \mathrm{SiC}$ grinding papers to a 2500 grit finish and then polished with successively finer grades of Buehler MetaDi monocrystalline diamond suspensions ranging from 30 to $1 \mu \mathrm{m}$ on Buehler polishing microcloths. The electrodes were rinsed with deionised water and ethanol, sonicated in a Branson 1510 ultrasonic bath and dried in a stream of air. The electrodes were polarised from $300 \mathrm{mV}$ below the corrosion potential, $E_{\text {corr }}$, at $1.0 \mathrm{mV} \mathrm{s}^{-1}$. Optical micrographs were recorded using an Olympus $\mathrm{B} \times 51 \mathrm{M}$ microscope at different magnifications in a dark-field mode. The micrographs were collected with a CCD camera (Leica DFC 2280 digital camera) and Olympus ${ }^{\circ}$ DP version 3.2 software.

The concentrations of $\mathrm{Fe}^{2+}$ and $\mathrm{Fe}^{3+}$ were estimated using a standard addition method. Rotating disc voltammetry (RDV) measurements were recorded with an EG\&G, Model 636, rotating disc electrode

Table 1

Composition of the electrolyte solutions, sww1 and sww2, $\mathrm{pH}=5.0$.

\begin{tabular}{|c|c|c|c|c|c|c|c|}
\hline & $\begin{array}{l}\mathrm{CaCl}_{2} \cdot 2 \mathrm{H}_{2} \mathrm{O} \\
\mathrm{g} \mathrm{L}^{-1}\end{array}$ & $\begin{array}{l}\mathrm{MgSO}_{4} \cdot 7 \mathrm{H}_{2} \mathrm{O} \\
\mathrm{g} \mathrm{L}^{-1}\end{array}$ & $\begin{array}{l}\mathrm{NaCl} \\
\mathrm{g} \mathrm{L}^{-1}\end{array}$ & $\begin{array}{l}\mathrm{PO}_{4}-\mathrm{P} \\
\mathrm{mg} \mathrm{L}^{-1}\end{array}$ & $\begin{array}{l}\text { Orange II } \\
\mathrm{mg} \mathrm{L}^{-1}\end{array}$ & $\begin{array}{l}\mathrm{Zn}^{2+} \\
\mathrm{mg} \mathrm{L}^{-1}\end{array}$ & $\begin{array}{l}\kappa \\
\mathrm{mS} \mathrm{m} \mathrm{m}^{-1}\end{array}$ \\
\hline sww 1 & 0.4 & 0.2 & 0.7 & 500 & 50 & 100 & 3.7 \\
\hline sww 2 & 0.4 & 0.2 & 7.0 & 500 & 50 & 100 & 14.4 \\
\hline
\end{tabular}


(a)

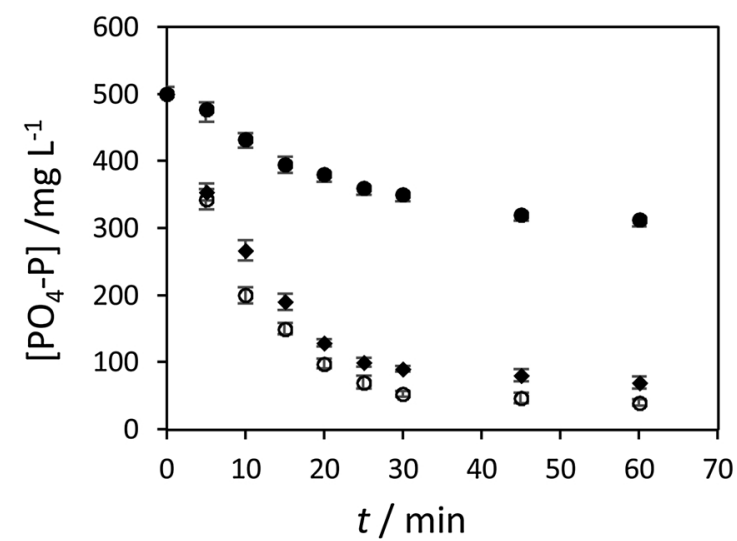

(c)

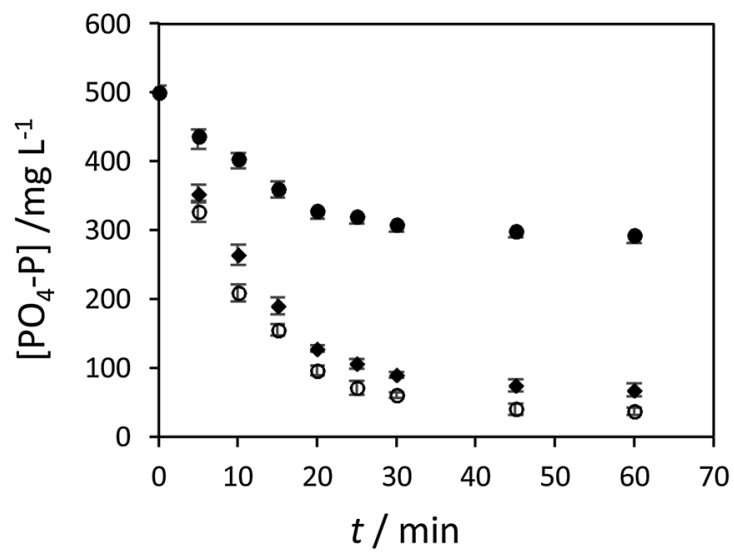

(b)

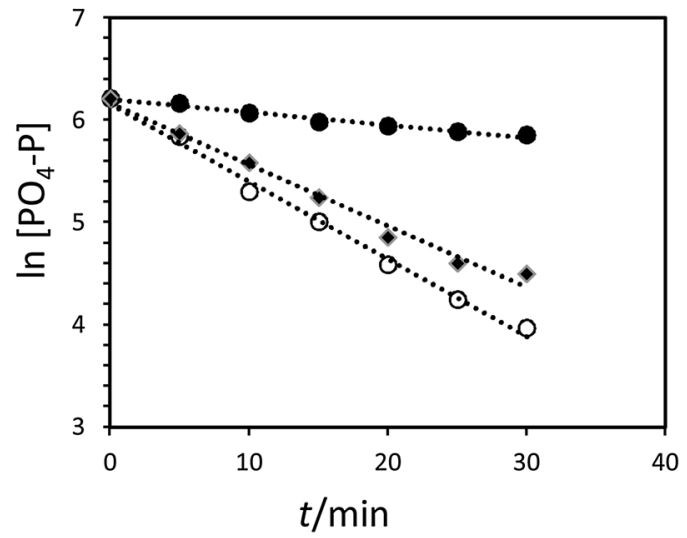

(d)

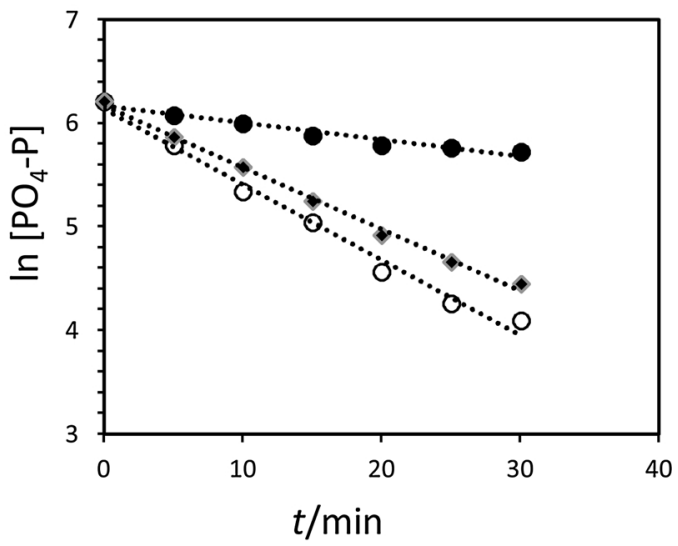

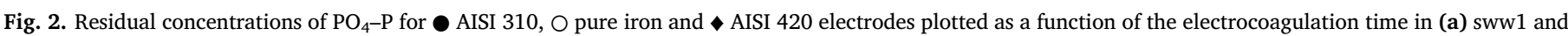
(c) sww2 and the logarithm of the $\mathrm{PO}_{4}-\mathrm{P}$ concentration plotted as a function of time in (b) sww1 and (d) sww2.

Table 2

Removal efficiencies $(\eta)$, at $60 \mathrm{~min}$ for phosphate and $30 \mathrm{~min}$ for orange II and $\mathrm{Zn}^{2+}$, and rate constants $(k)$ for iron, AISI 410 and AISI 310 in the removal of phosphate, orange II and $\mathrm{Zn}^{2+}$

\begin{tabular}{|c|c|c|c|c|c|}
\hline \multirow[t]{2}{*}{ Anode } & \multirow[t]{2}{*}{ Pollutant } & \multicolumn{2}{|l|}{ sww1 } & \multicolumn{2}{|l|}{ sww2 } \\
\hline & & $\eta / \%$ & $k / \min ^{-1}$ & $\eta / \%$ & $k / \min ^{-1}$ \\
\hline & Phosphate & & & & \\
\hline $\mathrm{Fe}$ & & 92 & 0.076 & 92 & 0.076 \\
\hline SS420 & & 86 & 0.060 & 88 & 0.064 \\
\hline \multirow[t]{2}{*}{ SS310 } & & 37 & 0.011 & 42 & 0.020 \\
\hline & Orange II & & & & \\
\hline $\mathrm{Fe}$ & & 98 & 0.126 & 99 & 0.130 \\
\hline SS420 & & 98 & 0.120 & 99 & 0.132 \\
\hline \multirow[t]{2}{*}{ SS310 } & & 29 & 0.009 & 30 & 0.010 \\
\hline & $\mathrm{Zn}^{2+}$ & & & & \\
\hline $\mathrm{Fe}$ & & 99 & 0.277 & 99 & 0.336 \\
\hline SS420 & & 99 & 0.208 & 99 & 0.327 \\
\hline SS310 & & 92 & 0.126 & 98 & 0.133 \\
\hline
\end{tabular}

following a 45-min electrocoagulation period, which was recorded in a simple $4.2 \mathrm{mM} \mathrm{NaCl}$ solution with no pollutants with an initial $\mathrm{pH}$ of 5.0 and a current density at $11.0 \mathrm{~mA} \mathrm{~cm}$. The solution was then acidified with $1.0 \mathrm{M} \mathrm{H}_{2} \mathrm{SO}_{4}$ in order to have complete dissolution of the iron flocs. All solutions were deoxygenated with nitrogen to prevent the oxidation of $\mathrm{Fe}^{2+}$ to $\mathrm{Fe}^{3+}$. The RDV measurements were recorded at $10 \mathrm{mV} \mathrm{s}^{-1}$ at a rotation speed of $3000 \mathrm{rpm}$ between $-0.20 \mathrm{~V}$ and $1.2 \mathrm{~V}$ vs
SCE.

\section{Results and discussion \\ 3.1. Removal of phosphates, Orange II and zinc ions}

The residual concentrations of phosphate, $\mathrm{PO}_{4}-\mathrm{P}$, plotted as a function of the electrocoagulation period in sww1 and sww2, are compared for pure iron, AISI 310 and AISI 420 electrodes in Fig. 2. It is apparent that the removal efficiency of AISI 310 is considerably lower than that observed with pure iron or AISI 420. The removal efficiency in sww1, over a 60 min period, was calculated as $92 \%$ for iron, $86 \%$ for AISI 420 and $37 \%$ for AISI 310. Again, in sww2, the highest removal efficiency is observed with pure iron and the AISI 420 electrodes. The rate of removal of the phosphates, $\mathrm{d}\left[\mathrm{PO}_{4}-\mathrm{P}\right] / \mathrm{d} t$, can be described by Eq. (3) and the corresponding pseudo first-order plots are presented in Fig. 2(b) and (d). The linear plots show that the removal of the phosphates follows first-order kinetics during the early stages of removal. The removal efficiencies and pseudo first-order rate constants, $k$, are summarised in Table 2, where it is evident that there is a significant variation in the two stainless steel electrodes. The removal efficiencies for the AISI 420 and iron electrodes are similar in sww1 and sww2, indicating that the higher chloride concentration and the higher conductivity of the sww2 solution has little effect on the dissolution of the electrodes. The conductivity and chloride concentration have more influence on the performance of AISI 310, with the rate constant 
(a)

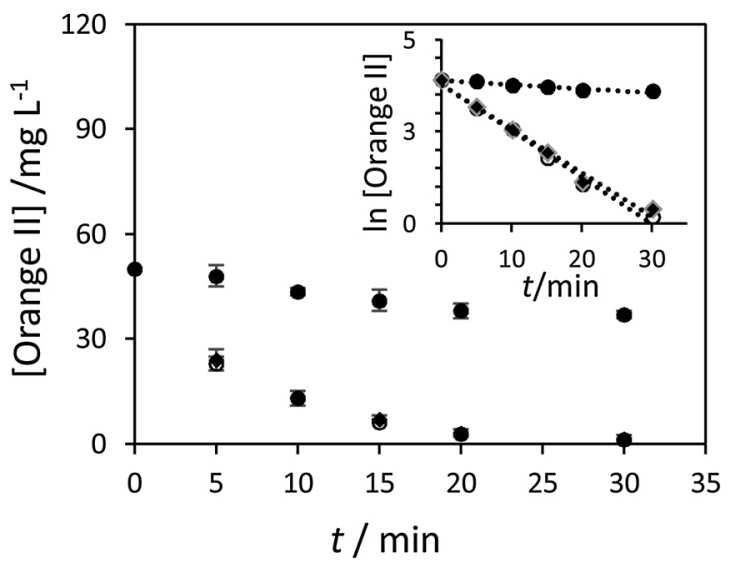

(b)

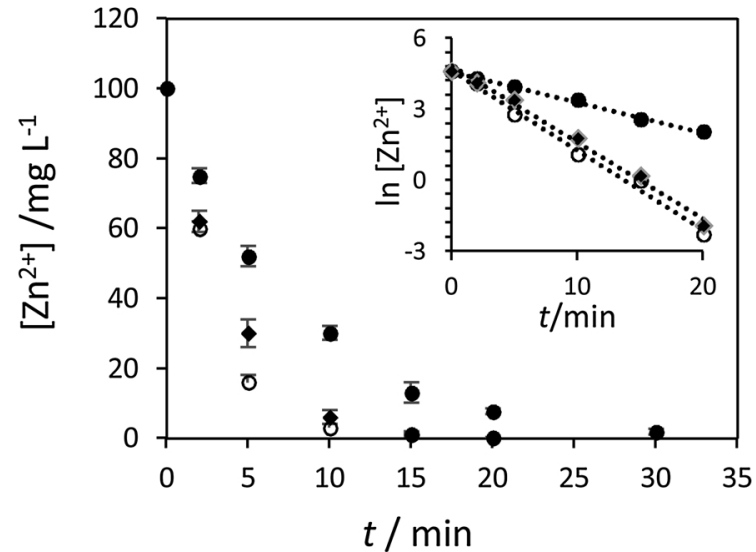

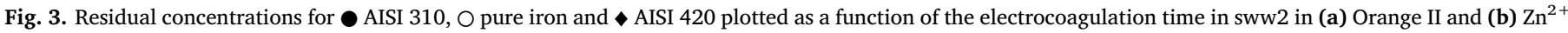
$(n=3)$. Inset shows the corresponding logarithmic plots.

increasing from $0.011 \mathrm{~min}^{-1}$ to $0.020 \mathrm{~min}^{-1}$ on replacing sww1 with sww2.

$\frac{d\left[\mathrm{PO}_{4}-P\right]}{d t}=k\left[\mathrm{PO}_{4}-P\right]^{\mathrm{x}}$

The residual concentrations of Orange II in the sww2 solution, plotted as a function of the electrocoagulation time, are shown for pure iron, AISI 310 and AISI 420 in Fig. 3(a), while the removal efficiencies and rate constants are summarised in Table 2. The corresponding pseudo first-order plots are shown in the inset. After $30 \mathrm{~min}$, the observed concentrations of Orange II are $0.5,0.7$ and $34 \mathrm{mg} \mathrm{L}^{-1}$ for pure iron, AISI 420 and AISI 310, respectively. Again, the removal of Orange II is efficient with pure iron and AISI 420, while poor removal is seen with AISI 310. The removal efficiencies calculated following a $30 \mathrm{~min}$ electrocoagulation period are similar in the sww1 and sww2 solutions, however the rate constants are higher in the sww2 solution, indicating that the variations in the conductivity and chloride concentration have some influence on the removal of Orange II, Table 2. Similar plots are shown in Fig. 3(b) for the removal of $\mathrm{Zn}^{2+}$ ions, where the residual concentration of $\mathrm{Zn}^{2+}$ is plotted as a function of the electrocoagulation time and the corresponding logarithmic plots are presented in the inset. The removal of $\mathrm{Zn}^{2+}$ ions is fully attained in $30 \mathrm{~min}$ for all three electrodes. However, the rate of removal is somewhat slower with the AISI 310 electrode, Table 2.

The formation of rust was observed at the iron electrode when it was immersed under open-circuit conditions and this resulted in the formation of a yellowish colour in the treated synthetic wastewater, in good agreement with previous reports [20-23]. This was not observed with the AISI 420 or AISI 310 anodes.

\subsection{Polarisation behavior of iron and stainless steel anodes in sww1 and} sww2

The electrochemical behaviour of AISI 310, AISI 420 and pure iron was studied using polarisation tests in the multicomponent media, sww1 and sww2. Representative polarisation plots, together with the corresponding micrographs, are shown in Fig. 4 for AISI 310, in Fig. 5 for AISI 420 and in Fig. 6 for pure iron. It is clear that the composition of the solution has a significant effect on the initiation, propagation and repassivation of pits in the case of AISI 310. In sww1, a passive current density of approximately $2.0 \times 10^{-6} \mathrm{~A} \mathrm{~cm}^{-2}$ is seen and this extends to high potentials to give an extended passivation region. The corrosion current was computed using the Tafel equation as $1.1 \times 10^{-6} \mathrm{~A} \mathrm{~cm}^{-2}$. As the chloride concentration is increased in sww2, breakdown of the passive film is seen at about $0.15 \mathrm{~V}$ vs. SCE. The surface morphology is shown in Fig. 4(b) and (c), where the micrographs were recorded following the polarisation plots. Pits reaching diameters of approximately $37 \mu \mathrm{m}$ are evident in sww1, while a higher density of pits, reaching diameters of about $50 \mu \mathrm{m}$ are observed in sww2, consistent with more dissolution in sww2. This enhanced dissolution in sww2 is apparent in the removal of Orange II and the phosphates, Table 2, where the rate constants and efficiencies are higher in sww2 when the AISI 310 anode is employed.

The polarisation behavior of AISI 420, Fig. 5 , is very different. The corrosion current is higher, at $1.0 \times 10^{-5} \mathrm{~A} \mathrm{~cm}^{-2}$. Furthermore, dissolution is seen at potentials that are only slightly higher than the corrosion potential, $E_{\text {corr }}$, between $-0.61 \mathrm{~V}$ and $-0.40 \mathrm{~V}$ vs. SCE, indicating that the passive film has relatively poor protective properties. The breakdown potential, corresponding to the onset of pitting attack, is seen at $-0.088 \mathrm{~V}$ vs. SCE in sww2 and at a slightly higher potential of $0.112 \mathrm{~V}$ vs. SCE in sww1, where the chloride concentration is lower. Irregular-shaped pits are evident at the end of the polarisation cycle. The polarisation curves shown for pure iron, Fig. 6, show no evidence of passive film formation with dissolution at potentials close to $E_{\text {corr. }}$. The corrosion currents, are nearly identical at $3.1 \times 10^{-5} \mathrm{~A} \mathrm{~cm}^{-2}$ in sww1 and $2.9 \times 10^{-5} \mathrm{~A} \mathrm{~cm}^{-2}$ in sww2. The accompanying micrographs show little evidence of large pits, with more general-like dissolution observed in both solutions. This is consistent with the data presented in Table 2, where there is little change in the rate constants when the sww1 and sww2 solutions are compared.

On comparing the polarisation curves to the removal efficiencies and rate constants, Figs. 2, and 3 and Table 2, it is clear that poor removal is associated with the formation of a passive film that limits dissolution and this is particularly apparent with AISI 310. The removal of phosphates will depend on the rate of dissolution of the anodes and the production of $\mathrm{Fe}^{2+}$ and $\mathrm{Fe}^{3+}$, where $\mathrm{Fe}^{2+}$ is oxidised to $\mathrm{Fe}^{3+}$ [26]. Good removal of $\mathrm{Zn}^{2+}$ is seen with both steel alloys and this suggests that the main removal mechanism is the precipitation of $\mathrm{Zn}(\mathrm{OH})_{2}$ due to the increase in the solution $\mathrm{pH}$ at the cathode in the cell. As the Orange II has an anionic $\mathrm{SO}_{3}-$ group, there may be some complexation between the dye and $\mathrm{Zn}^{2+}$ ions. However, as the $\mathrm{Zn}^{2+}$ ions are removed as $\mathrm{Zn}(\mathrm{OH})_{2}$, due to the availability of the $\mathrm{OH}^{-}$ions generated at the cathode, the shift in equilibrium should favour the un-complexed dye molecule. As a result, the Orange II will be involved in electrostatic interactions with the $\mathrm{Fe}(\mathrm{OH})_{\mathrm{n}}{ }^{3-\mathrm{n}}$ species facilitating its removal by surface complexation and adsorption. In addition, Patel et al. [27] attributed the removal of azo dyes to the cleavage of the azo bond, 

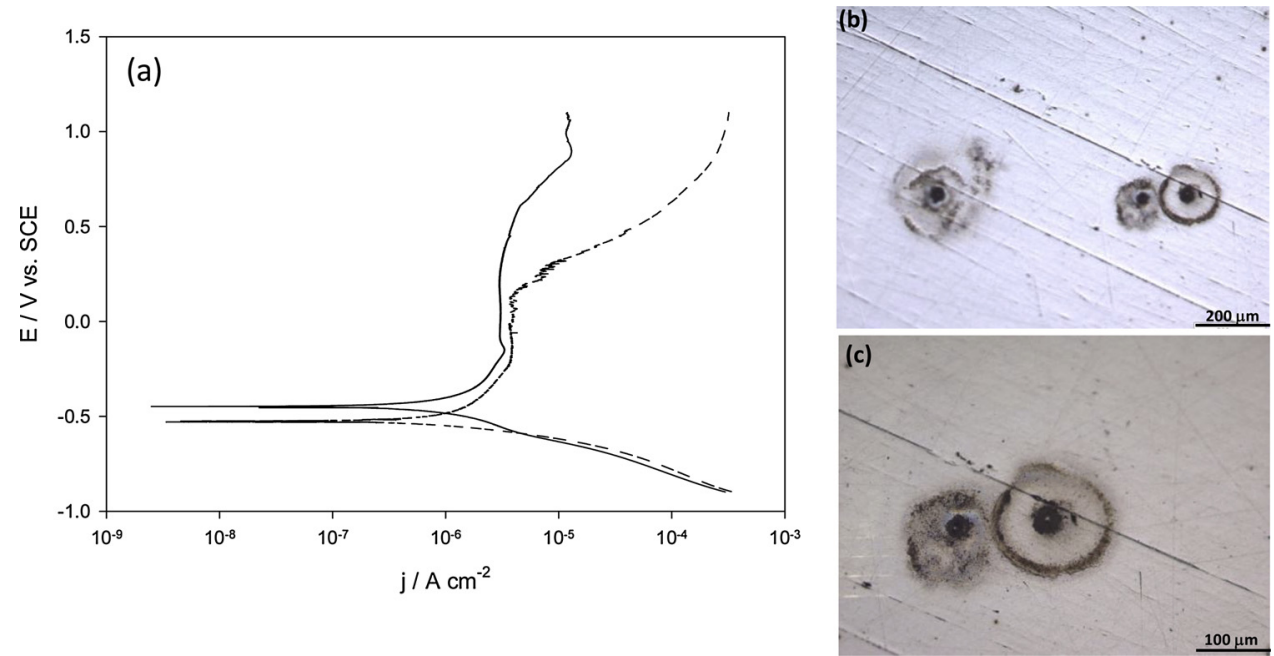

Fig. 4. (a) Polarisation curves for AISI 310 electrode in - sww 1 and - - - sww 2 at $1 \mathrm{mV} \mathrm{s}^{-1}$ and micrographs of AISI 310 in (b) sww2 and (c) sww1.

brought about by the $\mathrm{Fe}^{2+}$ ions released from the electrode which act as a reducing agent. As the AISI 310 anode is more passive it will adopt higher potentials in order to deliver the required current and consequently $\mathrm{Fe}^{3+}$ ions are likely to be generated, giving rise to particularly poor removal as cleavage of the azo bond in not achieved. While a passive film is formed with AISI 420, the relatively high passive current density of $3 \times 10^{-5} \mathrm{~A} \mathrm{~cm}^{-2}$ and the early onset of dissolution as the breakdown potential is reached gives the AISI 420 alloy removal efficiencies that come close to the values obtained with the pure iron system, while limiting the formation of rust.

\subsection{Anode dissolution and release of chromium}

As shown in Fig. 4 for the AISI 310 system, the current begins to increase at potentials above $0.90 \mathrm{~V}$ vs. SCE and this may be connected with trans-passive dissolution and the transformation of $\mathrm{Cr}(\mathrm{III})$ to the thermodynamically favoured soluble species, $\mathrm{HCrO}_{4}^{-}, \mathrm{Cr}(\mathrm{VI})$, giving rise to secondary pollution. Indeed, the presence of $\mathrm{Cr}(\mathrm{VI})$ was detected following the electrocoagulation treatment. Fig. 7 shows the UV-Vis spectrum of a representative sample. The coagulants and any sludge were removed and the solution was acidified to convert all the remaining chromium to the soluble chromium species, $\mathrm{Cr}(\mathrm{VI})$. The two characteristic absorption peaks for $\mathrm{Cr}(\mathrm{VI})$ at $260 \mathrm{~nm}$ and $370 \mathrm{~nm}$ are clearly evident [28], indicating its presence in the treated solutions. No $\mathrm{Cr}(\mathrm{VI})$ was detected following the electrocoagulation studies with AISI
420. This alloy also contains chromium however the more active dissolution will remove any $\mathrm{Cr}(\mathrm{VI})$ generated. Several studies have been reported on the removal of chromium by electrocoagulation [15,29]. The reduction of $\mathrm{Cr}(\mathrm{VI})$ to $\mathrm{Cr}(\mathrm{III})$ is facilitated by the generated ferrous ions, Eq. 4, and then the $\mathrm{Cr}(\mathrm{III})$ is removed as $\mathrm{Cr}(\mathrm{OH})_{3}$. Due to the low concentration of $\mathrm{Fe}^{2+}$ ions dissolved from the AISI 310 anode, the hexavalent chromium, $\mathrm{Cr}(\mathrm{VI})$, remains in both synthetic wastewaters, however if any $\mathrm{Cr}(\mathrm{VI})$ is released with the AISI 420 anode, this is removed as a sufficient concentration of $\mathrm{Fe}^{2+}$ is generated. Furthermore, as AISI 420 is less passive and dissolves more readily, dissolution is achieved at lower anode potentials and the alloying chromium is largely maintained in the solid state.

$\mathrm{CrO}_{4}^{2-}+8 \mathrm{H}^{+}+3 \mathrm{Fe}^{2+} \rightarrow \mathrm{Cr}^{3+}+3 \mathrm{Fe}^{3+}+4 \mathrm{H}_{2} \mathrm{O}$

\subsection{Dissolution and the generation of Fe(II) and Fe(III)}

The standard reduction potentials for the $\mathrm{Fe}^{3+} \mid \mathrm{Fe}$ and $\mathrm{Fe}^{2+} \mid \mathrm{Fe}$ couples are $-0.04 \mathrm{~V}$ and $-0.44 \mathrm{~V}$ vs. SHE, respectively. These thermodynamic values predict that the $\mathrm{Fe}^{2+}$ ions are formed at lower applied potentials, while the $\mathrm{Fe}^{3+}$ ions are generated at higher potentials. In order to determine if the oxidation state of the electrogenerated iron species is linked with the variations in the performance of the two steel alloys, the concentrations of $\mathrm{Fe}^{2+}$ and $\mathrm{Fe}^{3+}$ obtained on electrocoagulation were estimated. The concentrations of the $\mathrm{Fe}^{2+}$ and $\mathrm{Fe}^{3+}$
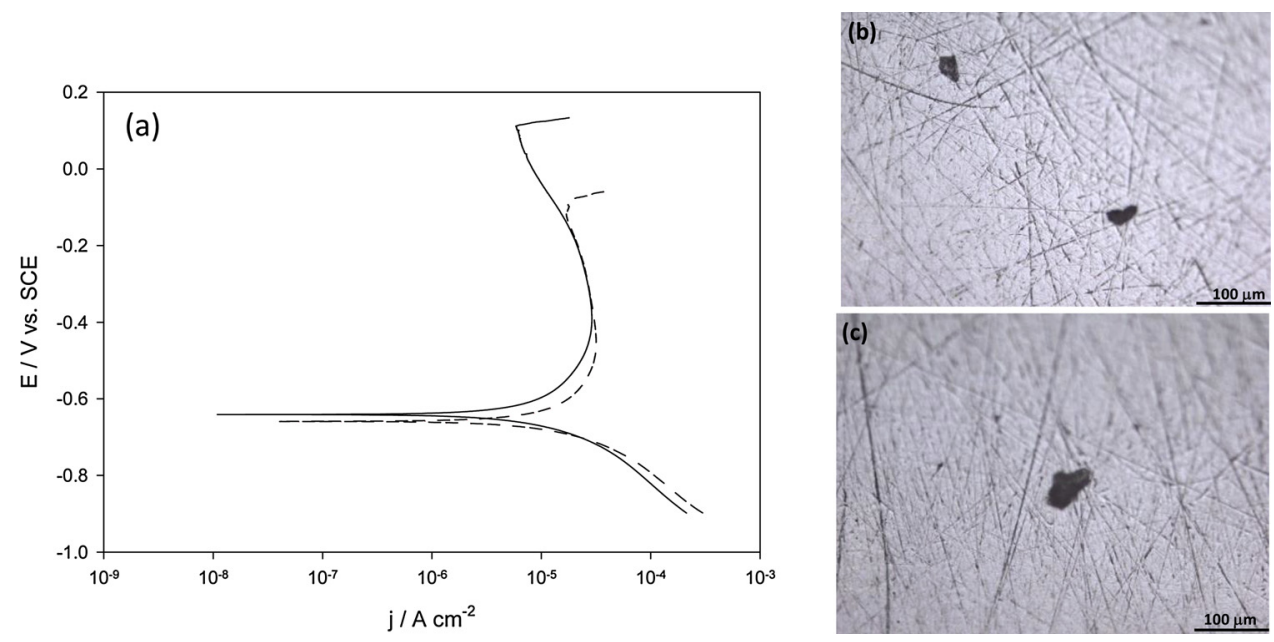

Fig. 5. (a) Polarisation curves for AISI 420 in — sww 1 and -- - sww 2 at $1 \mathrm{mV} \mathrm{s}^{-1}$ and micrographs recorded in (b) sww2 and (c) sww1. 

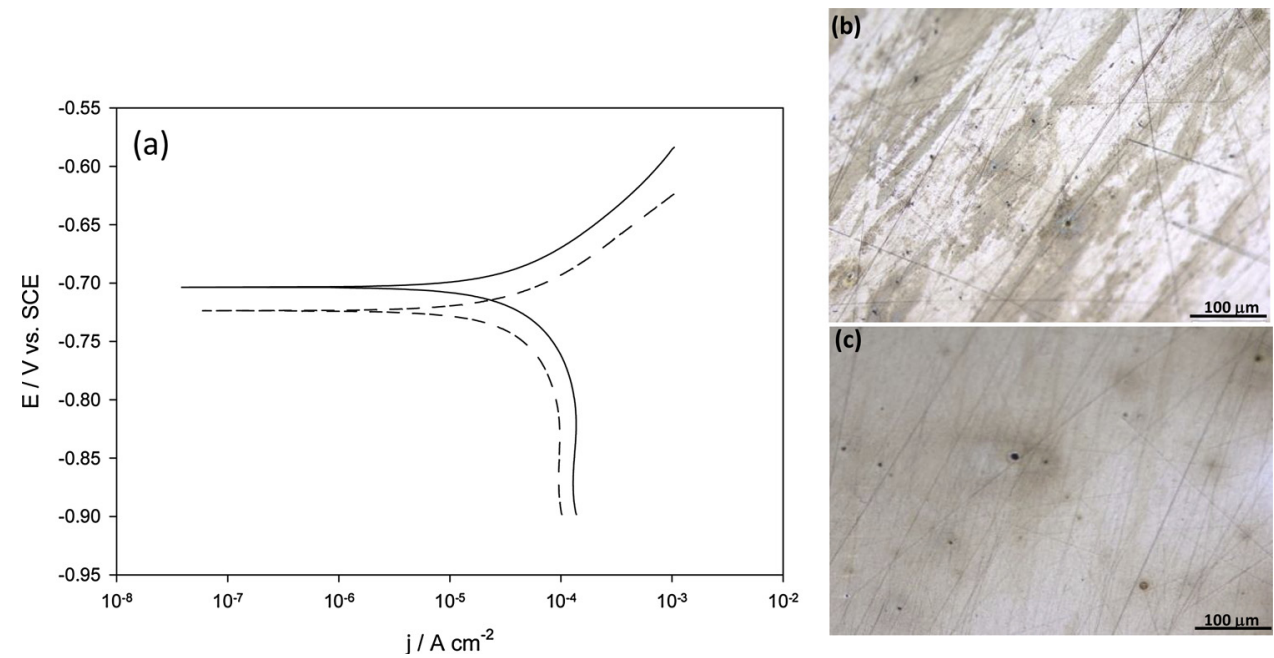

Fig. 6. (a) Potentiodynamic polarisation curves recorded at $1 \mathrm{mV} \mathrm{s}^{-1}$ for pure iron electrode in — sww1 and --- sww2 and micrographs recorded in (b) sww2 and (c) sww1.

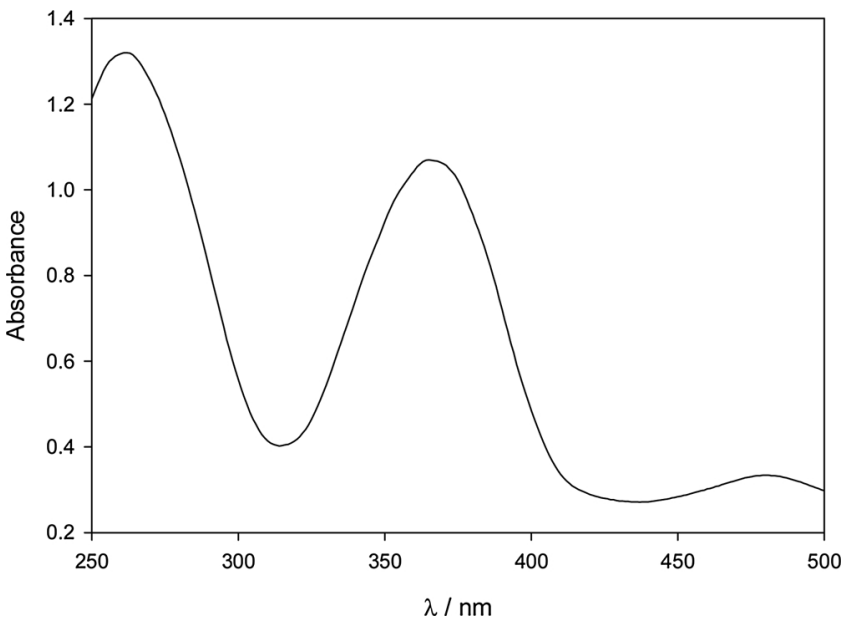

Fig. 7. UV-Vis spectrum recorded in sww2 following a 30-min electrocoagulation period using AISI 310 as the anode.

ions dissolved from the steel anodes were monitored using rotating disc voltammetry. In Fig. 8(a) a rotating disc voltammogram is shown at a rotation rate of $3000 \mathrm{rpm}$ for the solution obtained following electrocoagulation with AISI 420 in a simple $4.2 \mathrm{mM} \mathrm{NaCl}$ solution, without the addition of pollutants (dashed trace). All solutions were thoroughly deoxygenated and maintained under an atmosphere of nitrogen to prevent the oxidation of $\mathrm{Fe}^{2+}$ to $\mathrm{Fe}^{3+}$. This voltammogram is compared to the data obtained on addition of $\mathrm{Fe}^{2+}$ and $\mathrm{Fe}^{3+}$ to the solution, where the arrows indicate the direction of increasing concentrations. Oxidation of $\mathrm{Fe}^{2+}$ to $\mathrm{Fe}^{3+}$ is evident between $0.90 \mathrm{~V}$ and $1.2 \mathrm{~V}$ vs. SCE, while the reduction of $\mathrm{Fe}^{3+}$ to $\mathrm{Fe}^{2+}$ occurs at about $-0.20 \mathrm{~V}$ vs. SCE. Well defined limiting currents are seen. The concentrations of the $\mathrm{Fe}^{2+}$ and $\mathrm{Fe}^{3+}$ ions following the electrocoagulation experiment were measured by the standard addition method [30]. Serial increments of the standard $\left(\mathrm{Fe}^{2+}\right.$ or $\left.\mathrm{Fe}^{3+}\right), V_{\mathrm{s}}$, were added to a constant volume, $V_{\mathrm{x}}$, of the solution. The linear response is expressed by Eq. 5 , where $V_{\mathrm{x}}$ and $V_{\mathrm{s}}$ are the volumes and $C_{\mathrm{x}}$ and $\mathrm{C}_{\mathrm{s}}$ are the concentrations of the unknown and the standard, respectively, $N$ is the multiple units of addition, $k$ is a proportionality constant and $I_{L}$ is the limiting current. By plotting, the entire left hand side of Eq. 5, as Y, as a function of $N$ a straight line relationship with an intercept, $b$, and a slope, $m$, is obtained, and the unknown concentration, $C_{\mathrm{x}}$, is calculated using Eq. 6 .

$\left(V_{x}+N V_{s}\right) I_{L}=k V_{x} C_{x}+k V_{s} C_{s} N$ (a)

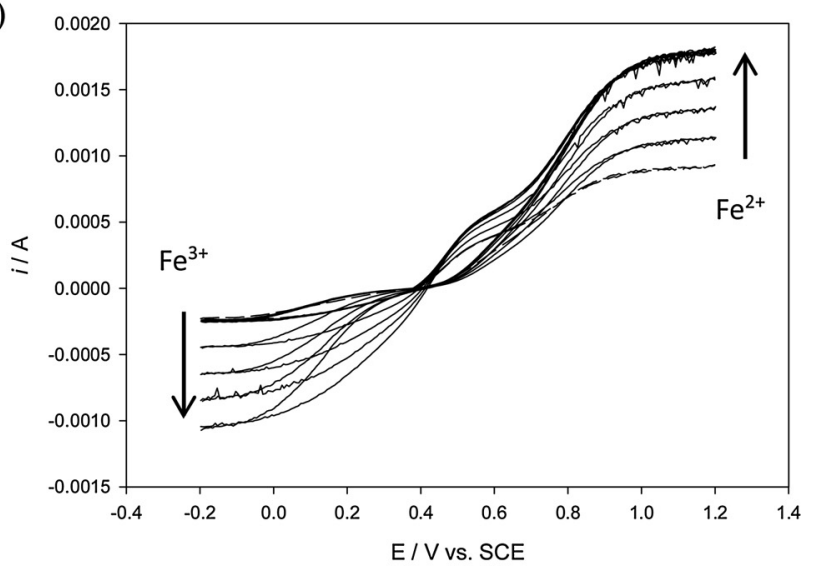

(b)

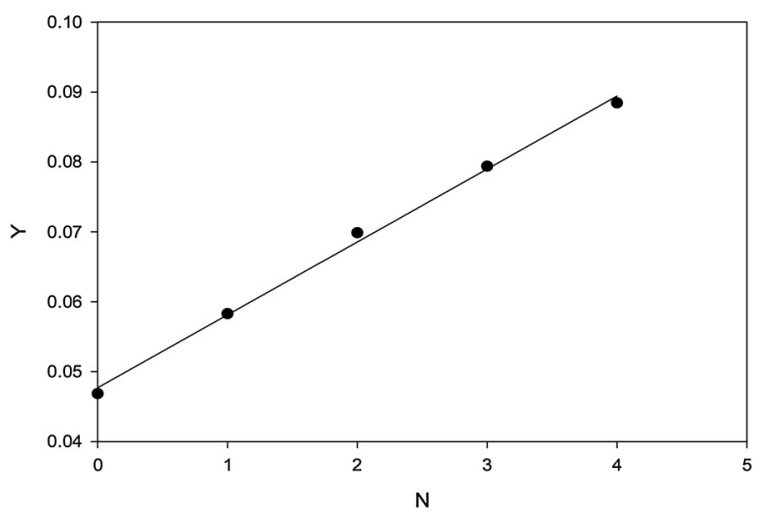

Fig. 8. (a) Rotating disc voltammograms recorded at $10 \mathrm{mV} \mathrm{s}^{-1}$ and $3000 \mathrm{rpm}$ with the addition of increasing $\mathrm{Fe}^{2+}$ and $\mathrm{Fe}^{3+}$ concentrations, (b) standard addition plot for $\mathrm{Fe}^{2+}$ where $\mathrm{Y}=\left(V_{\mathrm{x}}+N V_{\mathrm{s}}\right) I_{\mathrm{L}}$.

$C_{x}=\frac{b V_{s} C_{s}}{m V_{x}}$

A typical standard addition plot for $\mathrm{Fe}^{2+}$ is presented in Fig. 8(b) indicating good linearity. In Table 3 the concentrations of $\mathrm{Fe}^{2+}$ and $\mathrm{Fe}^{3+}$ obtained are shown and compared to the theoretical total ion concentration. The theoretical iron concentrations were computed using Faraday's law by considering a two- or three-electron transfer 
Table 3

Experimental and computed concentrations of $\mathrm{Fe}^{2+}$ and $\mathrm{Fe}^{3+}$ ions for AISI 420 $(n=3)$.

\begin{tabular}{|c|c|c|c|c|}
\hline \multicolumn{3}{|l|}{ Experimental } & \multirow{2}{*}{\multicolumn{2}{|c|}{$\frac{\text { Theoretical }}{\mathrm{Fe}_{\mathrm{TO}} \mathrm{mM}}$}} \\
\hline \multirow[t]{2}{*}{$\mathrm{Fe}(\mathrm{II}) \mathrm{mM}$} & \multirow[t]{2}{*}{$\mathrm{Fe}(\mathrm{III}) \mathrm{mM}$} & \multirow[t]{2}{*}{$\mathrm{Fe}_{\text {тот }} \mathrm{mM}$} & & \\
\hline & & & $\mathrm{z}=2$ & $\mathrm{z}=3$ \\
\hline $11.8 \pm 0.8$ & $1.60 \pm 0.03$ & $13.4 \pm 0.8$ & 13.86 & 9.24 \\
\hline
\end{tabular}

reaction. Taking into account the composition of the stainless steel electrode, the amount of iron is expressed by Eq. 7.

$m_{\mathrm{Fe}}=\left(\frac{\mathrm{It}}{F}\right)\left(\frac{W_{\mathrm{Fe}}}{Z_{\mathrm{Fe}}} f_{\mathrm{Fe}}\right)$

In this analysis, $m_{\mathrm{Fe}}$ is the mass of iron, $I$ is the current, $t$ is the time, $F$ is Faraday's constant, $W_{F e}$ is the atomic weight of iron, $Z_{\mathrm{Fe}}$ is the valence of iron $(\mathrm{Z}=2$ or $\mathrm{Z}=3)$ and $f_{\mathrm{Fe}}$ is the mass fraction of iron in the alloy. By comparing the concentrations obtained using the experimental and theoretical analyses, Table 3 , it is clear that good agreement is achieved using the $\mathrm{Fe}^{2+}$ species. Furthermore, a higher concentration of $\mathrm{Fe}^{2+}$ compared to $\mathrm{Fe}^{3+}$ is obtained experimentally. This suggests that $\mathrm{Fe}^{2+}$ ions are mainly produced on oxidation of the AISI 420 electrode. A similar analysis was performed with AISI310, however in this case, a much lower $\mathrm{Fe}_{\mathrm{TO}}$ value was obtained, estimated at $4.8 \mathrm{mM}$ and most of the iron was present as $\mathrm{Fe}^{3+}$, with $\mathrm{Fe}^{2+}$ at $0.5 \mathrm{mM}$ and $\mathrm{Fe}^{3+}$ at $4.3 \mathrm{mM}$. The generation of lower amounts of dissolved iron is consistent with the poor removal efficiencies evident in Figs. 2 and 3, the polarisation data presented in Fig. 4 where AISI 310 is easily passivated, while the presence of $\mathrm{Cr}(\mathrm{VI})$ in solution can be explained in terms of the low concentration of $\mathrm{Fe}^{2+}$. Furthermore, the low concentration of $\mathrm{Fe}^{2+}$ generated on dissolution of AISI 310 is consistent with the participation of $\mathrm{Fe}^{2+}$ in the reduction of azo dye molecules [27].

\section{Conclusions}

The results of this study show that AISI 420, a stainless steel alloy with $13-14 \% \mathrm{Cr}$ as an alloying component, dissolves to give relatively high concentrations of $\mathrm{Fe}^{2+}$. It has good efficiencies for the removal of phosphates, an organic dye molecule and $\mathrm{Zn}^{2+}$ ions and comes close to the efficiencies of pure iron, while limiting the formation of rust. However, on increasing the chromium content with the AISI 310 alloy, the removal efficiency was reduced considerably, the anode adopted higher potentials to give the required current and this in turn gave rise to trans-passive dissolution and secondary pollution by $\mathrm{Cr}(\mathrm{VI})$. This comparison clearly illustrates that the composition of steel alloys and in particular the chromium concentrations, are particularly relevant in electrocoagulation.

While AISI 420 compares well with pure iron, it is more expensive than iron. However, it is widely used in the oil and gas production industry and it is considerably cheaper than the highly corrosion resistant steel alloys. Given that it is stable and not consumed when the electrocoagulation unit is not in use, then it should function longer than iron, bringing the final costs closer. The simple schematic shown in Fig. 1, can be easily scaled up to include multiple anodes/cathodes that facilitate the flow of water through the unit, making it suitable for small-scale water treatment facilities.

\section{Acknowledgements}

The authors would like to acknowledge funding from the Irish Research Council, EMBARK initiative.

\section{References}

[1] S. Garcia-Segura, M.M.S.G. Eiband, J. Vieira de Melo, C.A. Martinez-Huitle, Electrocoagulation and advance electrocoagulation processes: a general review about the fundamentals, emerging applications and its association with other technologies, J. Electroanal. Chem. 801 (2017) 267-299.

[2] A.S. Naje, S. Chelliapan, Z. Zakaria, M.A. Ajeel, P.A. Alaba, A review of electrocoagulation technology for the treatment of textile wastewater, Reviews in Chem. Eng. 33 (2017) 263-292.

[3] M. Elazzouzi, Kh. Haboubi, M.S. Elyoubi, Electrocoagulation flocculation as a low-cost process for pollutants removal from urban wastewater, Chem. Eng. Res. Des. 117 (2017) 614-626.

[4] E. Lacasa, P. Canizares, C. Saez, F.J. Fernandez, M.A. Rodrigo, Electrochemical phosphates removal using iron and aluminium alloys, Chem. Eng. J. 172 (2011) 137-143.

[5] S. Irdemez, N. Demircioglu, Y.S. Yildiz, Z. Binguel, The effects of current density and phosphate concentration on phosphate removal from wastewater by electrocoagulation using aluminium and iron plate electrodes, Sep. Purif. Technol. 52 (2006) $218-223$

[6] M. Behbahani, M.R. Alavi Moghaddam, M. Arami, A comparison betweeen aluminium and iron electrodes on removal of phosphate from aqueous solutions by electrocoagulation process, Int. J. Environ. Res. 5 (2011) 403-412.

[7] N.S. Kumar, S. Goel, Factors influencing arsenic and nitrate removal from drinking waster in a continous flow electrocoagulation (EC) process, J. Hazard. Mater. 173 (2010) 528-533.

[8] N. Daneshvar, A.R. Khataee, A.R. Amani Ghadim, M.H. Rasoulifard, Decolorization of C.I Acid yellow 23 solution by electrocoagulation process: Investigation of operational parameters and evaluation of specific electrical energy consumption (SEEC), J. Hazard. Mater. 148 (2007) 566-572.

[9] M. Chafi, B. Gourich, A.H. Essadki, C. Vial, A. Fabregat, Comparison of electrocoagulation using iron and aluminium electrodes with chemical coagulation for the removal of a highly soluble acid dye, Desalination 281 (2011) 285-292.

[10] S. Aoudj, A. Khelifa, N. Drouiche, R. Belkada, D. Miroud, Simultaneous removal of chromium (VI) and fluoride by electrocoagulation-electrofloation: application of a hybride Fe-Al anode, Chem. Eng. J. 267 (2015) 153-163.

[11] M. Al-Shannag, Z. Al-Qodah, K. Bani-Melhem, M.R. Qtaishat, M. Alkasrawi, Heavy metal ions removal from metal plating wastewater using electrocoagulation : kinetic study and process performance, Chem. Eng. J. 260 (2015) 749-756.

[12] K. Govindan, A. Angelin, M. Rangarajan, Critical evaluation of mechanism responsible for biomass abatement during electrochemical coagulation (EC) process: a critical review, J. Environ. Management 227 (2018) 335-353.

[13] N. Boudjema, N. Drouiche, M. Kherat, N. Mameri, Wastewater disinfection by electrocoagulation process and its interaction with abiotic parameters, Desalin. Water Treat. 57 (2016) 28151-28159.

[14] P.K. Holt, G.W. Barton, C.A. Mitchell, The future for electrocoagulation as a localised water treatment technology, Chemosphere 59 (2005) 355-367.

[15] F. Akbal, S. Camci, Copper, chromium and nickel removal from metal plating wastewater by electrocoagulation, Desalination 269 (2011) 214-222.

[16] B. Merzouk, M. Yakoubi, I. Zongo, J.-P. Leclerc, G. Paternotte, S. Pontvianne, F. Lapicque, Effect of modification of textile wastewater composition on electrocoagulation efficiency, Desalination 275 (2011) 181-186.

[17] E. Yuksel, M. Eyvaz, E. Gurbulak, Electrochemical treatment of colour index reactive Orange 84 and textile wastewater by using stainless steel and iron electrodes, Environ. Prog. Sustain. Energy 32 (2013) 60-80.

[18] T. Olmez-Hanci, Z. Kartal, I. Arslan-Alaton, Electrocoagulation of commercial napthalene sulfonates process optimization and assessment of implementation potential, J. Environ. Manag. 99 (2012) 44-51.

[19] N. Modirshahla, M.A. Behnajady, S. Mohammadi-Aghdam, Investigation of the effect of different electrodes and their connection on the removal efficiency of 4-nitrophenol from aqueous solution by electrocoagulation, J. Hazard. Mater. 154 (2008) 778-786.

[20] X. Chen, G. Chen, P.L. Yue, Separation of pollutants from restaurant wastewater by electrocoagulation, Sep. Purif. Technol. 19 (2000) 65-76.

[21] G. Chen, Electrochemical technologies in wastewater treatment, Sep. Purif. Technol. 38 (2004) 11-41.

[22] F. Bouhezila, M. Hariti, H. Lounici, N. Mameri, Treatment of the OUED SMAR town landfill leachate by an electrochemical reactor, Desalination 280 (2011) 347-353.

[23] M.S. Secula, I. Cretescu, S. Petrescu, An experimental study of Indigo carmine removal from aqueous solution by electrocoagulation, Desalination 277 (2011) 227-235.

[24] OECD, Test No. 303: simulation test - aerobic sewage treatment - a: activated sludge units; B: biofilms, OECD Guidelines for the Testing of Chemicals, Adopted 22 (2011) January.

[25] G. Gonzales, E. Touraud, S. Spinelli, O. Thomas, Organic constituents, in: O. Thomas, C. Burgess (Eds.), UV-Visible Spectrophotometry of Water and Wastewater, Elsevier, 2007.

[26] S. Yeoman, T. Stephenson, J.N. Lester, R. Perry, The removal of phosphorus during wastewater treatment: a review, Environ. Pollut 49 (1988) 183-233.

[27] U.D. Patel, J.P. Ruparelia, M.U. Patel, Electrocoagulation treatment of simulated floor-wash containing Reactive Black 5 using iron sacrificial anode, J. Hazard. Mater. 197 (2011) 128-136.

[28] S. Tong, K. Li, The distribution of chromium(VI) species in solution as a function of $\mathrm{pH}$ and concentration, Talanta 33 (1986) 775-777.

[29] Z. Zaroual, J. Chaair, A.H. Essadki, K. El Ass, M. Azzi, Optimizing the removal of trivalent chromium by electrocoagulation using experimental design, Chem. Eng. J. 148 (2009) 488-495.

[30] B. Morris, A systematic approach to standard addition methods in instrumental analysis, J. Chem. Educ. 57 (1980) 703-706. 